\title{
Modern Food Sharing Networks and Community Integration in the Central Canadian Arctic
}

\author{
PETER COLLINGS, ${ }^{1}$ GEORGE WENZEL ${ }^{2}$ and RICHARD G. CONDON ${ }^{3}$
}

(Received 9 July 1997; accepted in revised form 6 March 1998)

\begin{abstract}
From June 1992 to July 1993, research on wildlife harvesting and subsistence relations was conducted among a sample of householders in the Inuit community of Holman. In an earlier paper, the authors examined the involvement of younger Inuit in subsistence hunting, noting that despite the sweeping political, social, and economic changes that have been experienced in Holman and across the Canadian North, hunting remained an important sociocultural and economic activity for some members of the sample group. This paper focuses specifically on the informal socioeconomic aspects of subsistence in Holman. Using primary data from the 1992-93 sample, we examine the range of economic mechanisms employed by Holman Inuit for the distribution of wild resources and compare the present range of such activity to that observed by Stefansson, Jenness, Rasmussen, and Damas in their work on Copper Inuit food sharing. These data indicate 1) that the sharing form most frequently cited ethnographically, obligatory seal-sharing partnerships, is more irregular than formerly; and 2) that voluntary, nonpartnershipbased sharing remains an important element in the contemporary economic system.
\end{abstract}

Key words: subsistence, Copper Inuit, food sharing, distributional mechanisms

RÉSUMÉ. De juin 1992 à juillet 1993, on a fait de la recherche sur les prélèvements fauniques et les rapports de subsistance parmi un échantillon de foyers dans la communauté inuit de Holman. Dans un article précédent, les auteurs étudiaient la participation de jeunes Inuit à la chasse de subsistance, notant que, malgré les changements profonds sur les plans politique, social et économique qui s'étaient produits à Holman et à travers tout le Nord canadien, la chasse restait une activité socioculturelle et économique importante pour des membres du groupe d'échantillonnage. Le présent article porte en particulier sur les aspects socio-économiques informels de la subsistance à Holman. En utilisant des données brutes provenant de l'échantillon de 1992-93, on se penche sur l'éventail des mécanismes économiques employés par les Inuit de Holman pour la distribution des ressources provenant de la nature et on compare l'éventail actuel de cette activité à celui qu'ont observé Stefansson, Jenness, Rasmussen et Damas dans leurs travaux sur le partage de la nourriture chez les Inuit du cuivre. Ces données indiquent 1) que le mode de partage le plus fréquemment cité par les ethnologues, c'est-à-dire le partenariat obligatoire du partage du phoque, est moins courant qu' auparavant; 2) que le partage volontaire, qui ne s'appuie pas sur le partenariat reste un élément majeur du système économique contemporain.

Mots clés: subsistance, Inuit du cuivre, partage de la nourriture, mécanismes de distribution

Traduit pour la revue Arctic par Nésida Loyer.

\section{INTRODUCTION}

Inuit food sharing practices have been of interest to northernists since explorers (Parry, 1824; Hall, 1865) and ethnographers (Boas, 1888; Stefansson, 1913) first reported them in the 19th and early 20th centuries. From the village-wide dispersal of bowhead whale products among North Alaska Inupiat (Spencer, 1959; Worl, 1980) to the seal-sharing partnerships of the Central Canadian Arctic Netsilik (Van de Velde, 1956; Balikci, 1970) and Copper Inuit (Damas, 1972a, b), pre-contact northern groups used a wide range of means to ensure the allocation of food resources within primary cooperating (mainly kinship- based) groupings and redistribution often situationally extending to entire communities.

Initially, Europeans conventionally saw sharing as a pragmatic essential of aboriginal existence in the Arctic. More recently (mirroring broader theoretical influences in hunter-gatherer studies), these practices have been interpreted as a core aspect of Inuit ecological relations (Steward, 1955; see also Damas, 1969a; Balikci, 1970) or, following Sahlins $(1965,1972)$, as a central theme of Inuit culture and identity (Hensel, 1992; Nuttall, 1992).

Despite professed interest in Inuit sharing, however, the northern literature has given little attention to the structural systematics of these behaviours. During the past

\footnotetext{
${ }^{1}$ Department of Anthropology, Pennsylvania State University, University Park, Pennsylvania 16803, U.S.A.

${ }^{2}$ Department of Geography, McGill University, Montreal, Quebec H3A 2K6, Canada; wenzel@ felix.geog.mcgill.ca

${ }^{3}$ Department of Anthropology, University of Arkansas, Fayetteville, Arkansas 72701, U.S.A.

(C) The Arctic Institute of North America
} 
several decades, as Wenzel $(1981,1995)$ has noted, research on Inuit subsistence has focused on quantifying its harvest component. As a result, these studies have neglected the social relations (which include sharing; Langdon, 1981; Wenzel, 1991) in which subsistence is embedded (but see Stevenson, 1997:295-303). This is not to deny that the Inuit gain important material and nutritional benefits from hunting and consuming country foods. Numerous studies have emphasized these benefits of hunting in small northern communities, especially those with limited employment opportunities (see, for example, Burch, 1985; Wenzel, 1987, 1989; Wolfe and Walker, 1987; Smith and Wright, 1989; Borré, 1990; Fall, 1990; Smith, 1991; Huntington, 1992). However, few such actionfocused studies include sharing as an essential element of Inuit subsistence relations.

In pre-contact times, food sharing was not an "automatic" process, but rather one contingent on ecological conditions, personal circumstances, and societal directives. In addition to providing for the distribution of critical resources, the act of sharing food emphasized the importance of individual generosity and obligations to kindred and community well-being. These cultural values and social practices thus were an important means for maintaining community cohesion.

The lack of treatment of sharing in many recent ethnographies has sometimes been interpreted as an indicator of a shift in cooperative ethos (see Buijs, 1993), if not cultural disarray, among the Inuit. This is particularly true with regard to the condition of Central Arctic Coast Inuit, where the seal-sharing partnerships frequently remarked upon in Copper and Netsilik Inuit ethnography and ethnology (Jenness, 1922; Rasmussen, 1932; Van de Velde, 1956; Balikci, 1964, 1970, 1984; Damas, 1969a, b, 1972a, b, 1984) are no longer discerned. The apparent disappearance of the piqatigiit (partnership) system, perhaps the single form of Inuit sharing widely cited beyond the specialized northern literature (see Price, 1975; Gardner, 1991), has been accepted as proof of the erosional effects of "modernization" (Remie, 1984; Buijs, 1993).

This paper reports on the sharing component of subsistence in the modern Central Arctic community of Holman. In an earlier paper (Condon et al., 1995), we analyzed participation by young Holman Inuit males and their associated households in the harvesting aspects of subsistence. At that time, the material and temporal elements of sharing were only briefly addressed. Here, we examine the social organizational attributes of contemporary Holman sharing behaviour to explain the social context of subsistence in the community.

The methods used in the collection of these data were substantially the same as those reported in our earlier paper (Condon et al., 1995). Briefly, data on sharing were collected as part of biweekly harvesting interviews conducted through the year with a sample of 20 households, each headed by a male between the ages of 20 and 35 . Included within the protocol was a section that specifically elicited the following information: 1) to whom participants had provided country food; 2) from whom they had received country food; 3 ) whom they had hosted for meals; 4) who had received them for meals; 5) the relationship between the individuals involved in these events. These data were recorded every two weeks over a 12-month period.

\section{THE COMMUNITY OF HOLMAN}

The Copper Inuit community of Holman is located on the western shore of Victoria Island in the Canadian Arctic Archipelago (Fig. 1). Most of the community's residents are descendants of the northernmost groups of Copper Inuit, although there are also a number of western Inuit/ Inuvialuit families who moved to the area in the 1920s and 1930s from the Mackenzie Delta and Banks Island areas (Usher, 1965; Condon, 1996).

The community was officially founded in 1939, when a Roman Catholic mission and a Hudson's Bay Company (HBC) post were established on the north side of the entrance to Prince Albert Sound. From the 1930s to the 1950 s, most of the region's Inuit remained dispersed in seasonal villages and camps for hunting, fishing, and trapping. Periodic trading trips were made to the HBC post to exchange fox pelts for southern foodstuffs (tea, flour) and manufactured goods (bolt cloth, leghold traps, rifles, and ammunition). The use of these items by the "Holman" population increased over time, paralleling the general trend among Inuit along the central Arctic coast.

In the early 1960s, the Canadian government (Condon, 1996; regarding general policy see Clancy, 1987; Damas, 1993) encouraged those Prince Albert Sound and Minto Inlet Inuit not yet resident in the community to resettle at Holman. Public housing and other services were provided to facilitate this process, which was completed by 1967 . Although many families continued to spend much of the spring and summer in hunting and fishing camps outside the settlement, the central social foci of life gradually shifted from the land to the village.

The settlement expanded dramatically during the 1970s and 1980s. In addition to more public housing, the territorial and federal governments provided educational, municipal, and health services, all of which were accompanied by wage employment opportunities. Today, Holman has a population of 423 living in 125 private or publicly financed dwellings, and boasts a large municipal office building, a school that includes Grades K through 9, a health centre, a community freezer, and several private businesses. The Holman Eskimo Co-operative, begun in the early 1960s, has expanded over the years to include a hotel, a retail outlet, a craft store, and a recently constructed, state-of-the-art print and carving studio. Additional retail services are provided by Northern Stores Inc.

Resettlement to Holman brought changes that affected participation in harvesting. One was the introduction of 


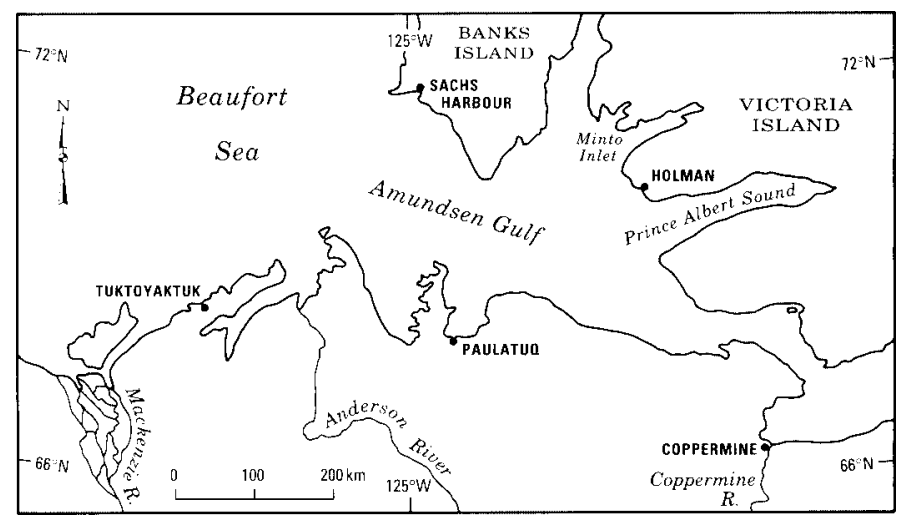

FIG. 1. Location of Holman in the Western Canadian Arctic.

formal education, first at the residential school in Inuvik and later locally in Holman, which, especially after school enrolment became compulsory, decreased the involvement of younger community members in harvesting. A second was the expansion of local wage opportunities, which took time from the harvesting involvement of the workers. Finally, several exogenous factors, chiefly access to new hunting technologies, a steady deflation in the price of fox pelts and, finally, the 1983-84 collapse of the European sealskin market, all worked to alter the involvement of individuals in land-based activities (see Condon, 1987; Collings, 1997).

I don't know if my grandson will be a good hunter. He's still young, and I don't want to say yet because maybe I am lying. It would be difficult to teach him because of school and being in town most of the year. My oldest son was following me around the trapline when he was six and a half. I bought him a machine [snowmobile] when he was seven. But kids have to go to school now. (Collings, 1992-93 fieldnotes)

Another change related to subsistence in Holman since resettlement has been an increase of the items present in the local diet. Before 1970, Inuit in the Holman region relied on fresh meat and fish for most of their caloric and nutritional needs. The Holman region was, and continues to be, rich in wildlife resources. Prior to about 1960, the imported staples purchased at the HBC post were mainly tea, tobacco, flour, sugar, and salt. Use of imported foodssoups, canned meats, and a wide range of high-carbohydrate products - gradually increased during the 1970s. By 1980 , the diet of many families had incorporated newly imported fresh food (frozen meats, fruits, and vegetables), but still contained a significant portion of starches and sugars (principally candy and soda). This shift from a high-protein, polyunsaturated fat diet to one high in carbohydrates and saturated fats, especially among the generation(s) raised in the settlement, has not been without adverse health effects (see Draper, 1976, 1978, 1980; Schaefer, 1971; also Borré, 1990).
Even though the younger households in the community are relying more upon southern foodstuffs, the sample members and their spouses whom we interviewed emphasized the importance of land food in their diet. Furthermore, they clearly recognized traditional food as an important component of contemporary village life. During our interviews, three major points emerged from people's discussions: 1) that land food is much healthier than nonInuit, or Qablunaat (Lowe, 1983), foods; 2) land food is fresh and therefore tastes better than food purchased at the local stores; 3) overall, country food is much less expensive to obtain. All three points are borne out both by empirical studies (Bell and Heller, 1978; Draper, 1980) and by research on Inuit dietary beliefs and attitudes (Wein and Freeman, 1992; Condon et al., 1995; see also Borré, 1994). A Holman family can survive solely on storebought food; however, few are willing to do so. Even fewer families are able to afford the high cost of frozen meats and fresh vegetables that would constitute a reasonably balanced diet. But perhaps most telling is that more than one study participant complained that Qablunaat food didn't taste very good because all the blood had been drained out of it.

In addition to having value for taste, health, and financial reasons, traditional foods are clearly essential to Inuit identity. This importance lies not only in their consumption, but also in their distribution throughout the community-so much so that the act of sharing may be said to literally and figuratively define indigenous food as different from Qablunaat food.

The reality of this distinctiveness is suggested by the following excerpt from an interview with a hunter in the study. After he had listed all the households with which he regularly shared land food, he was asked if there were any households with which he regularly shared southern food. The question obviously struck him as mildly amusing. In reply he smiled, nodded towards another hunter who had just walked in and helped himself to coffee and a sweet roll, and said, "Yes, I always let him have a Danish!" The comment was meant as a joke, but its meaning was clear: Qablunaat food may be shared situationally, but one would not take a box of frozen chicken wings to another household as a gift.

\section{THE COPPER INUIT SHARING SYSTEM: AN ETHNOGRAPHIC OVERVIEW}

Often within a community one man will show a special courtesy to another by sending him the hind flippers of every seal he catches....The two men thus become upatitkattik [transcribed as ukpatiqatigiik by Damas, 1972b:222], "flipper associates," a relationship that is independent of kinship ties, and involves no other obligation than the return of the compliment in the same manner. (Jenness, 1922:87) 
The little adopted daughter of the house, a girl of seven or eight, had not begun to eat with the rest of us, for it was her task to take a small wooden platter and carry the four pieces of boiled meat to the four families who had none of their own to cook. (Stefansson, 1913:176)

During our meal, presents of food were also brought us from other households; each...knew exactly what others had put into their pots, and whoever had anything to offer that was a little bit different would send some of that to the other. (Stefansson, 1921)

The first of the above quotes, from Jenness's Canadian Arctic Expedition ethnography, encapsulates the central, if not the only, feature of Copper Inuit food distribution that is generally referred to in popular and sometimes in scientific literature on Inuit sharing. In fact, the ukpatiqatigiik practice mentioned by Jenness, as Damas (1972b:223) notes, was in all likelihood just one element of the much broader piqatigiit (or seal-sharing partnership) subsystem detailed by Rasmussen (1932:106-107). This ordered, partner-based sharing was heavily emphasized later in the works of Van de Velde (1956), Balikci (1964, 1970), and Remie (1984), although these authors referred to the more easterly Netsilik Inuit. In fact, the emphasis placed by Netsilik scholars on this practice has to no small degree led non-specialists to conceptualize piqatigiit as the central, if not the only, form of Inuit sharing.

The piqatigiit subsystem of meat distribution holds significance for any discussion of contemporary sharing practices among Holman Inuit for several reasons. The first is that despite Stefansson's mention (1913:176-177) of at least one other type of sharing, it is seal partnerships (however, see Damas, 1972a, b, 1984) that dominate most recent discussions of Copper (and Netsilik [but see Kishigami, 1995]) Inuit sharing. In fact, the ethnographic record includes several other forms of sharing among the Copper Inuit that apparently functioned simultaneously with piqatigiit. Further, in contrast to Netsilik piqatigiit practice, Copper Inuit partnership sharing bridged the gap between kin and non-kin.

A second aspect of piqatigiit among the Copper Inuit is the seeming emphasis on exchange between same-generation kin partners (see Stevenson, 1997:300-301). This clearly differs from the systems present among other major Central and Eastern Arctic Inuit (see Damas's [1969c] comparison of Copper, Netsilik, and Iglulik societies; also Wenzel, 1995).

Finally, the apparent absence today of piqatigiit sealsharing partnerships among Holman Inuit, other Copper Inuit populations (for instance, Abrahamson, 1964), and the Netsilik (Kishigami, 1995) has been taken by some (see Remie, 1984; Buijs, 1993) as an indication of the overall demise of sharing as an element of Inuit socioeconomic life. For all these reasons, we can usefully examine the attributes of the several sharing subsystems that have been observed or reconstructed for the Copper Inuit, including the population now occupying the Holman-Prince Albert Sound region.

\section{Piqatigiit (Seal-Sharing Partnerships)}

Although Jenness (1922:87) and Rasmussen (1932:106107) both described partnership-based seal sharing, neither provided a complete picture of this subsystem. Jenness mentions only hind flipper associates; Damas (1972b:223), in fact, suggests that Jenness observed what was probably only one pairing within the more encompassing piqatigiit association. Rasmussen (see Table 1) provides a more extensive set of pairings, totaling 12 partnerships, all of which are referred to, as in the Jenness example, by a noun relevant to the ringed seal element exchanged, such as ukpati-, meaning hind flipper, plus the suffix -qatigiik, meaning companion. Damas (1972b), in his later reconstruction of this sharing form, details 14 named associations, which together provide a potential for 20 partnerships (the difference between terminological and actual partnerships exists because of the possibility of two associates for certain parts; for instance, there could be two flipper companions). Further, as Damas (1972b) described piqatigiit procedure, the actual reception by a partner of his assigned portion was rather more elaborate than either Jenness, Rasmussen, or various observers of Netsilik seal sharing (termed niqaiturvigiit [1972b:227]) suggest.

None of the research on piqatigiit as practised among the Copper Inuit is accompanied by any diagrammatic depiction of how ringed seals were actually divided among partners. However, Van de Velde (1956; see also Remie, 1984:103) illustrates the anatomical division of ringed seal as done in the Netsilik region, and this may roughly correlate with the scheme followed in the Copper Inuit region. Van de Velde (1956) also notes that, along with the elements designated for partners, the hunters reserved several parts of the seal (the right hind flipper, the skin, part of the fat and various organs and membranes) for the man who captured the seal (called the netjerta, or nitjira; Damas, 1972b:228), and other parts (the sanneraernerk, or sannirainiq, or flank slices; Damas, 1972b:228) were set aside for children. For the Copper Inuit, only Rasmussen (1932:106) indicates that specific portions are reserved for the successful hunter, and none of these schemata suggest that parts are set aside, as among the Netsilingmiut, for children.

Damas (1972b:224) notes that as extensive as the Copper Inuit piqatigiit partnership subsystem appears to have been, the reality may generally have been considerably more limited. He points out that only one of his informants (minimum sample $=20$ ) could name as many as 19 partners, though he does not give a mean number of partnerships. For his Netsilik data, Damas states that no informant could name more than seven sharing companions. He mentions (1972b), however, that his informants named the 
TABLE 1. Ethnographic summary of Copper Inuit sharing practices.

\begin{tabular}{|c|c|c|c|c|}
\hline Form & Source & Inclusiveness & Element & Term \\
\hline \multirow[t]{3}{*}{ Piqatigiit } & Jenness, 1922:87 & individual partner (1) & hind flippers & upatitkattik \\
\hline & Rasmussen, 1932:106-107 & individual partners (12) & $\begin{array}{l}\text { 1) hindquarters } \\
\text { 2) loin } \\
\text { 3) lower body } \\
\text { 4) shoulder } \\
\text { 5) blubber } \\
\text { 6) heart } \\
\text { 7) outer liver } \\
\text { 8) inside liver } \\
\text { 9) kidneys } \\
\text { 10) rectum } \\
\text { 11) lungs } \\
\text { 12) breast } \\
\text { 13) head, entrails }\end{array}$ & $\begin{array}{l}\text { pateqatige } \cdot k \\
\text { ilinneqatige } \cdot k \\
\text { akuamineqatige } \cdot k \\
\text { taleqatige } \cdot k \\
\text { urhuqatige } \cdot k \\
o \cdot m \cdot \text { ateqatige } \cdot k \\
\text { avaleraqatige } \cdot k \\
\text { hagleqatige } \cdot k \\
\text { tartuqatiger } \cdot k \\
\text { er }{ }^{\text {shuqatige }} \cdot k \\
\text { puaqatige } \cdot k \\
\text { hagiaqatige } \cdot k \\
\text { kaniva }{ }_{\text {ta }}, \text { qo }^{\prime} \cdot v_{i k}\end{array}$ \\
\hline & Damas, 1972b:223 & individual partners (18) & $\begin{array}{l}\text { 1) stomach } \\
\text { 2) heart } \\
\text { 3) liver } \\
\text { 4) flipper (2) } \\
\text { 5) lower back } \\
\text { 6) hind quarters } \\
\text { 7) shoulder (2) } \\
\text { 8) breast side (2) } \\
\text { 9) fat (2) } \\
\text { 10) lower spine } \\
\text { 11) neck } \\
\text { 12) large intestine } \\
\text { 13) lower ribs } \\
\text { 14) stomach }\end{array}$ & $\begin{array}{l}\text { aquabiniqatigiik } \\
\text { uummatiqatigiik } \\
\text { tinguqatigiik } \\
\text { taliqatigiik } \\
\text { ilingniqatigiik } \\
\text { ukpatiqatigiik } \\
\text { akhatquqatigiik } \\
\text { hakiaqatigiik } \\
\text { uqhuqatigiik } \\
\text { kuyaqigaqatigiik } \\
\text { qunguhiqatigiik } \\
\text { iqhuqatigiik } \\
\text { hitamaukkaaqatigiik } \\
\text { aqiaruqatigiik }\end{array}$ \\
\hline \multirow[t]{4}{*}{ Payuktuq } & Stefansson, 1913:176-177 & open & boiled meat/presents & \\
\hline & Jenness, 1922:90 & open & meat/fat & \\
\hline & Damas, 1972a:25 & voluntary & & \\
\hline & Damas, 1972b:225 & voluntary "carrying" & & \\
\hline \multirow[t]{6}{*}{ Commensal } & Stefansson, 1913:177 & open & presents & \\
\hline & Jenness, 1922:90 & "visitors" & & \\
\hline & Rasmussen 1932:129 & open & frozen salmon and dried caribou & \\
\hline & Damas, 1969c:48 & voluntary & & \\
\hline & Damas, 1972a:24-25 & village-wide & & \\
\hline & Damas, 1972b:226 & village, via household hosts & & \\
\hline \multirow[t]{2}{*}{ Other } & Rasmussen, 1932:105 & open & bearded seal: owner retains head and skin & others - taglägtut, qo. $v_{\text {in. }}$ ätut \\
\hline & Condon et al., 1995:41 & open (“ubiquitous") & all foods & \\
\hline
\end{tabular}

ukpatik (hind quarter) as the most frequent partnership pairing, followed closely by the ilingnik (lower back) partnership.

\section{Other Mechanisms}

Payuktuq: Along with piqatigiit, the Copper Inuit used several other mechanisms to distribute food. However, in contrast to the highly structured partnership subsystem, these other forms apparently functioned solely on a voluntary or ad hoc basis.

The first of the quotations from Stefansson that began this section exemplifies the practice of payuktuq. In general, payuktuq is the giving or carrying of food, whether fresh or cooked, to another individual or household. Researchers have often emphasized the role of piqatigiit distribution in Copper Inuit sharing. However, it is clear that payuktuq also figured prominently in the overall system, as shown not only by the observational evidence of Stefansson, but also by Damas's several references (1972a, b) to payuktuq volunteerism.

As described by Damas (1972b:225), Copper Inuit payuktuq "involved sending portions of seals not distributed according to the piqatigiit system to the houses of the villagers not included in the successful hunter's network of partners." Stefansson's (1913:176) mention of temporary shortages among the families to whom food was sent therefore seems consistent with the information on payuktuq elicited by Damas. Further, Damas (1972b:225) notes that payuktuq also frequently occurred between co-resident families: "Voluntary food gifts within ...residential complexes appear to have been common."

It also appears, although it is by no means certain (see Damas 1972a:25), that the piqatigiit subsystem functioned only in relation to ringed seal. Therefore payuktuq gifting probably represented an important means of distributing other important food species not included within the framework of piqatigiit partnership, such as caribou, muskox, 
arctic char, and polar bear (but see Rasmussen [1932:105] regarding the distribution of bearded seals).

Commensalism: Damas (1972a, b, 1984) states that communal eating was another important means of sharing food in the Copper Inuit region, just as it was for other Central and Eastern Arctic Inuit (Damas, 1972b; Wenzel, 1991, 1995). As in neighboring Netsilik and Iglulik-North Baffin societies, where such meals are termed nirriyaktuqtuq, Copper Inuit commensalism was apparently practised village-wide (Damas, 1969c:48, 1984:402).

However, in contrast to the way communal meals were conducted among these more easterly groups, where only the leaders of restricted ilagiit (understood here as the unit composed of households headed by consanguinally linked males only [see Balikci, 1964; also Damas, 1969c; Wenzel, 1995]) initiated such gatherings, Copper Inuit practice appears to have revolved around well-provisioned households without regard to a host's position within an extended family. As Damas (1972b:226) notes, "most of the meat that was not immediately consumed remained in the possession of the individual hunter...he had exclusive ownership." This observation is borne out by Jenness (1922:90) who, with apparent reference to caribou, notes that the food (and skins) acquired by an individual are owned by him; the only caveat is that "all or some...must be shared with the neighbors."

Damas (1984:402) points out, not surprisingly, that communal meals were especially frequent during the summer, when most cooking was done in the open. It also seems that communal eating was the preferred manner for major meals (Damas, 1972b:226); however, despite constant commensalism, there was no set pattern to such visitations.

Among northern Baffin Island and Foxe Basin Inuit, nirriyaktuqtuq meals are usually limited to a specific food item (see Wenzel 1995:49), and all the food is contributed by a single source, usually from the supply held by an ilagiit leader (contemporary exceptions are meals sponsored by the Anglican Church and hamlet government). However, the second quotation from Stefansson (1913:177) above indicates the possibility that such item or source exclusiveness was not always the case in Copper Inuit practice. The passage appears rather to suggest that payuktuq and nirriyaktuqtuq practices may have been at least situationally combined (see also Jenness, 1922:90).

\section{The Organization of the Copper Inuit Sharing Complex}

While key elements of Netsilik, Iglulik, and North Baffin Inuit sharing are based on kinship relations (see Damas, 1969c:48, 1972b; also Balikci, 1964; Wenzel, 1995), Copper Inuit sharing activities, as described ethnographically, appear to have lacked such structure. Indeed, the core structural association that affects reciprocal relations on northern Baffin Island and among Iglulingmiut, membership in an ilagiit (with sharing operating through what Wenzel [1995:46-47] has termed the tugagaujuq-tigutuinnaq subsystem), appears to be notably absent in the Copper Inuit region. This apparent deviation from more easterly Inuit practice is, however, consistent with other anomalies of Copper Inuit social organization, namely the isolation of the nuclear family and the absence of extended family (isumataaq) leadership (Damas, 1976).

This is not to say that kinship and extended family relations precluded piqatigiit or payuktuq sharing between individuals (as Damas [1972a, b] notes, sharing could include members of a hunter's kindred), but rather that kinship was not a determining factor in such participation. Damas (1972b:224), in fact, makes it clear that the preponderance $(74 \%)$ of piqatigiit pairings revealed by his informants included individuals for whom respondents could apply a kinship term. While the percentage of kin (versus non-kin) in his Copper Inuit sample is relatively low when compared to primary sharing group data from Clyde River, Baffin Island (Wenzel 1991, 1995), it is nonetheless substantial.

What is revealing, however, is that the Copper Inuit data (Damas 1972b:224) include categories of kin-notably cousins related to ego (the person of reference in kinship analyses) through women, or arnaqatigiit (father's sister's son, mother's brother's son, and mother's sister's son)that together form 26 of the 79 identified kinship pairings (>32\%) in his piqatigiit sample. In contrast, Clyde Inuit sharing is dominated by primary consanguinal male relations (ego's father, father's brothers and their sons, and male siblings), followed by primary male affines (ego's father-in-law, ego's wife's older male siblings).

Thus, almost one-third of these Copper Inuit "kinsmen" would generally not be included in the East Baffin system (see Damas, 1975; Wenzel, 1981). When arnaqatigiit are added to the $26 \%$ of true non-kinsmen in Damas's sample, nearly $60 \%$ of the piqatigiit partners reported to Damas by Copper Inuit informants would be excluded from the core sharing feature at Clyde River, the extended family tugagaujuq-tigutuinnaq subsystem.

Damas (1972a, b) also makes it clear that payuktuq sharing among the Copper Inuit, while it could also include direct kinsmen, did not place any primacy on such relations. Further, whereas commensal practices among North Baffin, Iglulik, and Netsilik Inuit all functioned in association with extended family organization, this was not the case (see Stefansson, 1913; Jenness, 1922; Damas, $1969 \mathrm{c}, 1972 \mathrm{a}, \mathrm{b})$ in the Copper Inuit area. Thus, statements about the voluntary nature and wide-scale inclusion of allaqiit (others) in Copper Inuit sharing consistently reflect the unique breadth of kinship relations in that population described to Damas (1975:13) as ilaruhariit, which encompasses categories of kin beyond the ilagiit core (including male ego and spouse, their parents, and the siblings, with spouses and children, of the central couple; see also Balikci [1964:61] regarding the Netsilik "extended ilagiit"). 


\section{CONTEMPORARY PATTERNS OF HOLMAN FOOD SHARING}

In contemporary Holman, food sharing, while obviously present (see Condon et al., 1995:41-43), also seems on first appearance to be highly idiosyncratic and variable. In fact, however, modern sharing does take a variety of forms, ranging from highly formalized gift giving to the informal sharing of prepared meals. While the nature of Holman food sharing is partially dependent upon such factors as the current availability of a particular species, the social and emotional closeness of the households involved, and the personal circumstances of the givers and receivers, closer examination of sharing reveals some underlying patterns that correspond closely to ethnographic descriptions of payuktuq and commensal food distribution.

\section{Payuktuq Sharing}

According to Damas (1972b), payuktuq sharing included the practice of distributing seal meat to households not included in the piqatigiit subsystem, but it is also clear that other foods (see Jenness, 1922:90) were so distributed. Indeed, the most common forms of payuktuq sharing may have generally occurred during the caribou hunting and fishing phases of the traditional seasonal round, for it was during these seasons that families separated into smaller groups and the piqatigiit system could not apply. Jenness (1922:87) wrote:

Looser and more temporary ties are sometimes contracted. Two men will arrange to spend a summer together in a certain district, and naturally, during this period, a good deal of mutual assistance is required....A man who possesses a rifle will sometimes associate with one who has none. This enables the two men to take turns in hunting, and while one with his bow and fishing gear wanders off after birds and fish, the other will take the rifle and scour the country for caribou....it constitutes a bond of union between them, a not unimportant link in the welding together of the heterogeneous elements of the community.

Today, payuktuq appears to be the most frequent type of resource distribution practiced among Holman Inuit. Such gifting, according to contemporary informants, remains voluntary in nature and in its general form closely resembles ethnographic descriptions of payuktuq. However, despite the apparently eclectic distributional "pattern" resulting from this voluntarism, project data suggest that payuktuq giving can be discriminated into three loose subtypes; free access, invitation, and carrying sharing, each identified mainly through the relationship of the receiver to the giver.

The most frequently recorded form of payuktuq activity within our sample occurred between study households and
TABLE 2. Payuktuq sharing, Holman household sample, $1992-93^{1}$

\begin{tabular}{lrc}
\hline \hline Source & \# Events & \% Total Events \\
\hline A. Food Receiving: & & \\
Male spouse's parents & 105 & 35.4 \\
Female spouse's parents & 82 & 27.7 \\
Male spouse's siblings & 35 & 11.8 \\
Female spouse's siblings & 11 & 3.7 \\
Male spouse's "uncles"2 & 33 & 11.1 \\
Female spouse's "uncles"2 & 8 & 2.7 \\
First cousins (either spouse) & 10 & 3.4 \\
Second cousins (either spouse) & 11 & 3.7 \\
Grandparents (either spouse) & 1 & 0.3 \\
Elders (non-relatives) & 0 & 0 \\
Non-Natives & 0 & 0 \\
& & \\
Total & 296 & 99.8 \\
& & \\
B. Food Giving: & & \\
Male spouse's parents & 68 & 24.5 \\
Female spouse's parents & 28 & 23.4 \\
Male spouse's siblings & 65 & 7.6 \\
Female spouse's siblings & 21 & 7.6 \\
Male spouse's "uncles"2 & 21 & 2.5 \\
Female spouse's "uncles"2 & 7 & 5.0 \\
First cousins (either spouse) & 14 & 2.5 \\
Second cousins (either spouse) & 7 & 5.4 \\
Grandparents (either spouse) & 15 & 1.4 \\
Elders (non-relatives) & 4 & 9.7 \\
Non-Natives & 27 & 99.7 \\
Total & 277 & \\
\hline \hline
\end{tabular}

${ }^{1}$ Number of sample households $=20$

2 The term "uncle" appears to have been used somewhat nebulously by some respondents within the household sample. Thus, for some households, this category includes persons other than those who are actually pangnaaryuk (father's brother) or angak (mother's brother) to one responding spouse or the other.

those of primary consanguinal (parents, siblings) or close affinal (ego's spouse's parents and siblings) affiliation (see Table 2) through what we here term "free-access sharing." Sample members gave food to these categories of relations in $65.6 \%$ of 277 events recorded and, conversely, obtained food from these same categories in $78.6 \%$ of 296 recorded "receiving" actions.

For the sample households, receiving food generally meant that either spouse went to a provider's home or meat locker in the community freezer and helped herself or himself to any available fresh meat or fish. On the other hand, the giving of food, especially to parents or grandparents, invariably involved the delivering of a requested item or portion to the home of the recipient. Presumably this difference in the pattern of receiving, as opposed to giving, behaviour relates to the frequently genealogically subordinant position of sample household adults $(<35)$ with respect to other participants. (Collings, in inquiring about payuktuq operations, was often told that it is better to give than to receive [unpubl. 1992-93 Holman field notes])

Free-access sharing most often took place immediately after a successful hunter returned to the settlement. Relatives would come and help themselves to fresh meat, 
sometimes aiding in the butchering and processing as well. At other times, family members would help themselves to the meat and fish in a hunter's food box or freezer, more often than not without asking permission or even informing the hunter of the removal.

The preponderance of free-access payuktuq distributional events affecting the sample households over the study year involved the receiving of country food (Table 2 , Part A) from one or the other parent set in $63.1 \%(n=187$ events) of occurrences. Of the total 187 such receiving actions, 105 (35.4\%) involved food from the parents of male study participants, while $82(27.7 \%)$ involved food from the parents of females. The siblings provided food in a further $15.5 \%$ of the remaining occurrences $(n=46): 35$ events $(11.6 \%)$ involved the siblings of male household heads, and $11(3.7 \%)$ involved females' siblings. The remaining 63 receiving events $(21.2 \%$ of the total) involved sample members' "uncles" (in 33 events [11.1\%], uncles related through male sample members, and in 8 [2.7\%] events, uncles related through women in the sample); first and second cousins (21 events [7.1\%]); and grandparents ( 1 event $[0.3 \%]$ ).

"Giving" (Table 2, Part B) was mainly directed to parents, siblings, or grandparents in 197 (71.1\%) of 277 recorded actions. Such giving was strongly biased toward the relations of male household heads (133 of 197 events, or $67.5 \%$ of the total). "Uncles," cousins, and unrelated elders were involved in only $53(19.0 \%)$ giving events, while non-Inuit were the recipients of food in a further 27 $(9.7 \%)$ events.

A situational aspect to giving may lead to the inclusion of only distantly related, and even unrelated, individuals. Inclusion in such cases most usually occurs when assistance is provided in the butchering of an animal, either in the field or, less commonly, in the community. In this circumstance, reception of some portion of meat is predicated solely on participation at the time of processing; however, the receiver appears to be free to choose whatever portion is desired.

Invitation sharing includes both close relatives and more distantly related or nonrelated households; it is analogous to the practices of akpallugiit and akpaaqtauyuq described (see Damas, 1972b:232) for Iglulik and Netsilik Inuit, respectively. A hunter either calls others on the telephone or mentions in face-to-face conversation that he has meat and that the individual is welcome to take some. In all cases, the burden is placed upon the invitee to come to the household to get meat, thus testing the resolve of receivers to enter into this particular exchange or allowing them to decline without being forced to say no. When an invitee accepts by appearing at the household, the hunter or the hunter's spouse distributes a specific portion to the receiver.

The carrying subtype generally involves only socially distant households and closely resembles payuktuq sharing as described by Damas (1972b) and Wenzel (1995), respectively, for the Iglulingmiut and East Baffin Inuit.
Unlike the two previous subtypes, this form requires the hunter or his spouse to physically transport food to another household. Recipients of this payuktuq type are usually the aged and infirm in the community, or others who might otherwise lack access to land foods. This type of distribution can also include resident non-Inuit, who frequently lack significant access to land foods. However, unlike the situation that prevailed when food was delivered to a parent, the type or portion of food involved in this form of payuktuq was at the discretion of the giver.

Ultimately, however, this last type can include any Inuit household in the community, and is an overarching means, as the following excerpt (Collings, unpubl. 1992-93 Holman field notes) indicates, for obtaining country food. During a social visit, J., who was experiencing serious snowmobile problems, commented that there were lots of people out hunting over the weekend and that he hoped that they would come back with lots of meat because he really wanted to buy some from somebody. L. (a non-relative) overheard this and said, "Why would you want to buy caribou meat? I still have some left in my freezer." When J. asked how much, L. responded, "a little bit; maybe a half of a half." L., however, did not invite J. to draw from his supply. Instead, L. dropped off a "half of a half" at J.'s house the next day.

\section{Commensalism}

In addition to the above types of payuktuq sharing, the hosting of communal meals was an important third mechanism of resource allocation among the Copper Inuit in the past and remains an important and highly valued way of sharing food in Holman at present. Such gatherings are variously referred to today as niqikaktatut or niqikatigiit. It appears that communal participation in meals could and still does occur in two forms, each differentiated by one or the other of the above reference terms: the first is limited to those who are present when meat is being served, and the second, more open type closely resembles nirriyaktuqtuq behaviour as it has been described for Netsilik and Iglulik Inuit societies (see Damas, 1972b; Wenzel, 1995).

The pattern followed in the more limited form was described by Jenness (1922:90):

When a meal is in progress every stray visitor who looks in for a moment must be offered something, even if it be only a tiny morsel of meat or fat. The man may be exceedingly unwelcome, but his hostess would hardly dare to neglect him for fear of public disapproval...

While such behaviour concerning meals and visitors is common in other Central and Eastern Arctic groups, the lack of emphasis on the extended family in Copper Inuit society (in contrast to the situation in North Baffin and the Iglulik and Netsilik areas, where ilagiit members may 
gather several times each week to eat with the extended family head) suggests that such shared meals should be treated as a commensal type.

The practice of this form of communal eating is still widely followed in Holman today and continues with only minor changes. Although the community has grown larger in the sense that there are more people and more households, visitors upon entering a house are invariably offered food. Such sharing generally means feeding a visitor if he or she happens to arrive during a meal, but may be no more than the offer of a snack, to be consumed with tea and conversation. In younger households, especially those of less active hunters, such snacks often include store-bought food such as cookies or crackers. By and large, however, "snacks" consist of leftovers from the evening meal: dried or frozen meat and fish, or bannock.

Another increasingly common form of such limited commensalism is the inviting of relatives and friends to partake in a formal (that is, scheduled) meal. An invitation is typically made by telephone or by sending a messenger, usually a child from the hosting household, to the invited household(s). Such invitations, however, are usually unplanned and are, therefore, more spontaneous than they otherwise might appear.

The second "type" of communal eating, termed here "open commensalism," also occurs in the modern community, but much less frequently. This type more closely resembles the "classic" nirriyaktuqtuq meals (see Damas, 1972b, 1984; also Wenzel, 1995:49) of eastern Inuit groups than either of the two previously mentioned gatherings. Rasmussen's (1932:129) description of one such Copper Inuit communal meal is fairly typical: "There were twentyfive people in the house, apparently the youth of the village...all being fed on frozen salmon and dried caribou meat."

Damas (1969c:48) notes that such commensal meals could involve an entire village. This custom contrasts with Clyde and Iglulik Inuit nirriyaktuqtuq activities, which, although often attended by many participants, are almost always organized today through the leader of an ilagiit. However, when nirriyaktuqtuq is practised in camp circumstances at Clyde, where participation is necessarily limited to the several co-resident families (see Wenzel, 1994), commensal meals are considerably more spontaneous. Also, commensal meals in the Eastern Arctic are less likely to involve more than a single food (see Wenzel, 1995:49; also Rasmussen, 1929:241) as described for the Copper Inuit by Rasmussen and Stefansson (1913:177).

That such "open" nirriyaktuqtuq meals are relatively infrequent in Holman is not surprising for several reasons. First, even wide-scale commensalism among the Copper Inuit was organized on a voluntary, household-to-household basis (see Damas (1972b), and apparently it still is today. Second, the size of the present community, approximately 425 Inuit, far exceeds that of any pre-resettlement aggregation. Thus, it is difficult for a single household to obtain resources sufficient for such a community-wide activity.

\section{Other Exchanges}

Sharing occurs in several other forms that do not correspond to either the communal eating or to payuktuq patterns of food distribution. These forms, which have apparently arisen in response to the demands of settlement life and the cash economy, are exchanging food for services, exchanging food for cash, and theft. They are relatively uncommon within the community and in some cases are antithetical to prevailing ethics regarding food exchange.

The exchange of food for services is relatively uncommon and occurs only between socially distant households. In a very real sense, it is a form of balanced reciprocity in which an individual receives an item or service and reciprocates with a gift of food. Observation and interviews indicate that overall, these balanced exchanges are a minor mechanism for distributing food. Some cases are clearly examples of immediate balanced reciprocity, while others are more subtle and can appear to be more generalized. In one instance, a household in our sample gave some old furniture to a young, unmarried mother, and the next day her older brother visited with a gift of caribou meat.

The cash sale of food between Inuit in the community is unheard of, although individuals might mask a request for food by offering to pay for it, as in the case cited in the section on payuktuq. Nevertheless, Inuit do sell land food for cash, and it is a legitimate activity. In most such cases, food is sold to transient construction workers. The Co-op hotel also purchases a limited amount of char, caribou, and muskox meat for use in its restaurant. Those who engage in selling meat are almost always hunters who do not have regular jobs and still pursue a mixed strategy of temporary or seasonal wage labor and subsistence hunting. Selling small amounts of meat significantly boosts their household income, and the cash generated is invariably invested in further subsistence activities.

Last is outright theft. Our conversation with village residents revealed many complaints about the theft of land food from campsites and lockers in the community walkin freezer. Land food is not the only target of thieves, as thefts of gas, naphtha, oil, and supplies cached in camps on the land were also mentioned. Most Inuit believe that stealing is a growing problem in the community, and during our fieldwork there were several incidents of food vanishing from people's food boxes and front porches. Some of these "thefts" may have been relatives who were helping themselves to food or loose dogs running off with unsecured game, but other cases were clearly incidents of stealing. Potential thieves are encouraged by the relative anonymity with which they can act and the breakdown of gossip networks and informal methods of social control and conflict resolution (see Condon, 1992).

\section{Piqatigiit}

Seal-sharing partnerships, the most discussed element of pre-contact Copper Inuit sharing, are, at least on first 
appearance, conspicuously absent from the inventory of sharing behaviours in the modern community. They are worthy of some treatment for that reason alone. Since some have interpreted this "disappearance" as an indicator of the breakdown of sharing among Inuit generally, piqatigiit, or rather its absence from modern Holman, must be examined.

The piqatigiit subsystem, as Jenness (1922:87) and others have noted, was a sharing form that exclusively involved ringed seals (although Damas [1972a:25] mentions that in summer it may have included fish and caribou). Unlike other food distribution mechanisms of the Copper Inuit, pigatigiit defined partners formally on the basis of the parts of a seal they exchanged with each other. An individual could thus have up to 20 partners (Damas, 1972b:224).

Piqatigiit partnerships frequently involved non-kinsmen. Damas (1972b:224) recorded that fully $26 \%$ of the partnerships recalled by his sample members were with individuals for whom no kinship term could be supplied. However, as pointed out earlier, piqatigiit relations were strongly biased toward several categories of cousins, although Damas (1972b) also notes that four cases of brotherbrother partnerships occurred among his sample, and that partnerships were often formed between men within the same age cohort. In fact, as Damas points out (1975:12), piqatigiit relations very much reflected the generalness of Copper Inuit social organization, in which generational affiliation was critical and ilaruhariit was at least as functionally important as the ilagiit. Damas states with regard to associating behavioural significance to the usage of kinship terminology, "work among the Copper Eskimo is...frustrating" (1975:12).

The piqatigiit system clearly emphasized the interdependence of hunters as individuals, as opposed to stressing membership within the virilocal (to mean a marital residence pattern dominated by the male spouse's kin) extended family, as among more eastern Inuit societies. Moreover, this subsystem seems to relate strongly to a social, structural, and sociodemographic pattern in which openness and mobility were emphasized over the social and residential coherence of the Iglulik and North Baffin Inuit and, to a somewhat lesser degree, the Netsilik.

Whether the piqatigiit subsystem is indeed absent from the modern community is, however, far from clear. While Condon et al. (1995) did not observe any clear expression of piqatigiit during the course of their harvesting and subsistence research, follow-up work by Collings in 1996 (unpubl. field notes) elicited the adamant response that partnerships (aulukitigiit) still exist today.

However, whether this "relationship" refers to actual hunting partners or simply to persons with whom one travels is not completely clear (aullaaq generally translates as "to travel" [see Lowe, 1983]), nor is it clear how enduring aulukitigiit "relations" may be. The meaning of aulukitigiit is further confused by the use in Holman of an anglicized variant, audloaking, which means "to go camping." In any case, several informants insisted that piqatigiit still exists as an active practice and that such relations are continued even among younger hunters, noting that the scope of piqatigiit sharing today includes not only seals but also caribou, muskox, and fish. However, Collings (1996, unpubl. Holman field notes) also records that informants freely interchange the terms payuqtigiit and piqatigiit.

The most likely, albeit still hypothetical, explanations for the possible disappearance of formal piqatigiit terminological referents among Holman people, even if the material practice of partnered sharing continues, may relate to several factors. Among these are changed sociodemographic arrangements precipitated by residential centralization, changes to the local economy, and changing hunting practices.

One outcome of centralization may have been increased residential and social group stability. The mobility that was an important component of earlier Copper Inuit ecological relations thus altered markedly, as it has throughout the Central and Eastern Arctic, as a result of the central place policy begun by the Canadian government in the 1950s. Under the resulting circumstances, the structured pattern of dyadic resource allocation that occurred under piqatigiit, notably when items were scarcer, no longer has its former importance. Instead, payuktuq and commensal practices provide all the "insurance" (Damas, 1972b:227) that is needed under modern settlement conditions.

Second, seal hunting by Holman Inuit has declined dramatically in recent years (Smith and Wright, 1989). This development is partly due to the collapse of the European market for sealskins (Wenzel, 1991) in 1983; however, it is unclear just how important ringed seal has been, at least in recent times, as a dietary item in the community. Most 1993 study participants, albeit all under the age of 35, expressed a clear preferencefor caribou, followed by fish and muskox, for food (see Table 3; also Condon et al., 1995).

Whatever the importance of the food preference factor, it is clear that until the early 1980s, ringed seal were extensively pursued by Holman Inuit. Fur sales from Jelliss (1978:3) indicate that until the European Community sealskin boycott, Holman ranked as the third-largest seal hunting community in the Canadian Arctic. The magnitude of this decline is apparent when the 2438 ringed sealskins traded by Holman Inuit in 1978-79 (unpubl. NWT fur export records) are compared to the total of 1372 ringed seals captured by community hunters in 1990 (Fabijan, 1991). This decline is further measureable by computing the average seal harvest per Holman hunter from Jelliss's 1976-77 figures (Jelliss, 1978:3). In that year, 52 hunters captured a mean number of 95 ringed seals each (as derived from sales data only); in 1984, Smith and Wright (1989:95) reported that a sample of 18 harvesters had an average catch of just 27 animals each.

Third, the last several decades have seen a significant change in Holman Inuit seal harvesting strategy. Few if 
TABLE 3. Holman sample land food consumption, August $1992-$ July $1993^{1,2}$

\begin{tabular}{lrr}
\hline \hline Evening meals with land foods (all types)/total meals & $271 / 533$ & $(51 \%)$ \\
Caribou & $121 / 271$ & $(45 \%)$ \\
Muskox & $56 / 271$ & $(21 \%)$ \\
Ringed seal & $7 / 271$ & $(3 \%)$ \\
Waterfowl & $37 / 271$ & $(14 \%)$ \\
Fish (all types) & $57 / 271$ & $(21 \%)$ \\
Arctic hare & $2 / 271$ & $(0.74 \%)$ \\
Polar bear & $1 / 271$ & $(0.37 \%)$ \\
\hline \hline
\end{tabular}

${ }^{1}$ Source: Condon et al., 1995: Table 8.

${ }^{2}$ The data presented pertain to only 16 sample households.

any hunters currently hunt seals by waiting at breathing holes, a situation that surprised one resident originally from Gjoa Haven. Holman harvesters today always use rifles and, more significantly, prefer to hunt at the permanent lead usually found about $8 \mathrm{~km}$ offshore. Here they wait for seals to surface, shoot them with high-powered rifles, and retrieve them with seal hooks and small boats. Possibly this change in method has affected the demographics of seal hunting task units: cooperation among several hunters is less important than it was formerly, when hunting took place at seal breathing holes.

One other factor, which partially relates to all of the above, is also worthy of consideration. Younger hunters, partly because of the demands of formal education (see Condon, 1987), spend less time in winter hunting activities, and thus lack the familiarity of older hunters with the sea ice environment. Indeed, most young people express a fear of sea ice and the open water.

As hunting of caribou and muskox requires somewhat less specialized knowledge (Condon et al., 1995), and considering that the land may be more forgiving of mistakes by relatively inexperienced hunters, younger harvesters clearly seem less engaged by sealing than even the hunting generation of the 1970s. Further, the economics of harvesting now mitigate against relatively low-return activities (such as sealing, compared to caribou or muskox hunting). It is plausible that ringed seals are generally less important to the overall economy and, thus, to the resource distribution system, especially as payuktuq and commensaltype sharing seem to provide adequately for community needs.

\section{CONCLUSIONS}

Of the Central Arctic Inuit groups examined by Damas $(1969 b, c)$, precontact Copper Inuit social organization alone emphasized the primacy and autonomy of the nuclear family household at the expense of other, more complex social organizational features. Given what may have been a more problematic biophysical environment than that inhabited, for instance, by the Iglulik Inuit, for whom large sea mammals, especially walrus, were readily available, individual household autonomy, seasonal mobility, and dependence upon intragenerational relations were absolutely necessary for survival. This set of features, not surprisingly, is consistent with a system of resource sharing that maximizes openness.

In modern Holman, however, kinship ties appear to have emerged as a salient aspect of payuktuq food distribution and sharing practices. More than ever before, to judge from the ethnographic record, food sharing is likely to involve close relatives, with a strong male bias in payuktuq activity as indicated in Table 2 . Among younger households, food sharing practices may actually involve only closely related households, especially the parents of both male and female spouses, the siblings of male spouses, and "uncles" related to the male household heads. Indeed, when the pattern of sharing events participated in by individual sample members is discriminated, the flow of resources given and received is dominated by ties of close kinship (74.9\% of all receiving events and $58 \%$ of all giving events recorded involved the parents of either spouse or siblings of the male heads of household).

One possible explanation for this change, presuming that the ethnographic record accurately portrays the openness of sharing before centralization (but see Damas, $1972 b$ ), is that in a growing, permanent community individuals simply have more siblings and close collateral relatives available than was the case in their grandparents' time. Nonetheless, to conclude that the current food distribution system is now kinship-dominated and ilagiit-centred remains problematic, given informants' insistence on the continued presence of a form of "open" piqatigiit sharing.

It appears that Holman food sharing today functions under the same caveat described by Jenness (1922:90):

The family owns all the food and skins that are acquired by any of its members, with this restriction, that all or some of the food must be shared with the neighbours. The amount that is kept by the family for itself depends on the quantity of food in the camp at the time. If ten seals, for example, are caught in one day, and there are only six families in the camp, it is obviously unnecessary to send more than a tiny portion of the meat to each household. On the other hand, if only one seal is caught, the whole of the meat must be distributed, otherwise some of the people would go hungry.

Although scarcity does not exist as it did then, there are indications that the sharing retains the flexibility to broaden in perceived times of need. During the period of our harvesting research, caribou were extremely scarce, as the herds that normally winter in proximity to town had moved farther away. The lack of caribou alarmed many residents, some of whom commented that they were "starved for caribou" (Collings, 1997).

Many Holman Inuit thus resigned themselves to eating muskox, which remained locally abundant, although they 
clearly preferred caribou. However, when hunters did return from nominally successful caribou hunts, the meat was distributed throughout the community. One hunter, upon returning with three caribou, immediately distributed the bulk of this harvest, sending meat to 14 different households, including several homes not linked by kinship, while keeping only one-half of one caribou for himself. At the same time, muskox or fish were not distributed with the same emotional intensity, nor did they often find their way to more distant households.

Our data suggest that food sharing in Holman has remained coherent over time, but has experienced two related and possibly significant structural changes: the loss of the dyadic piqatigiit subsystem and the emergence of kinship (but see Damas, 1969a) as a central and distinct factor in country food distribution. The decline of piqatigiit partnerships, if they have indeed declined, is at least partially the result of material changes involving strategies of hunting, the collapse of the seal market, and the relative ease of access to other wild foods across the community. But also significant, both to this decline and to the emergence of a kinship-biased sharing pattern, notably in the payuktuq subsystem, is the residential stability experienced by the Prince Albert Sound-Northwest Victoria Island Inuit population over the past 30 years.

Sharing in Holman continues in spite of such changes, albeit in a socioeconomic environment in which the formerly most important mechanism facilitating food sharing, piqatigiit seal partnerships, apparently functions in a more constricted and decidedly less formal manner. The practices that are most widely operational, however, retain the Copper Inuit emphasis frequently described ethnographically on voluntary behaviour, and the household remains the focal structural feature at all levels of exchange. Moreover, given the emphatic response of Holman informants in affirming the continuation of piqatigiit-like behaviour, if not the continued use of actual named partner terminology, it appears that the ethos of piqatigiit remains an important aspect of contemporary Holman identity.

\section{ACKNOWLEDGEMENTS}

This research was made possible by a grant from the National Science Foundation, Division of Polar Programs (Grant \#9110708). The authors are indebted to the Hamlet Council and all the residents of Holman, especially participants in the 199293 harvest research, for their unstinting assistance. Finally, we thank Patricia Draper and Pamela Stern for their insightful comments on earlier versions of this paper, as well as Jack Kruse and two anonymous referees. All errors, of course, are solely our own. Finally, we (Collings and Wenzel) dedicate this paper to the late Richard Guy Condon, our colleague, collaborator, banjo specialist and close friend, who set it on its course.

\section{REFERENCES}

ABRAHAMSON, G., ed. 1964. The Copper Eskimos: An area economic survey, 1963. Area Economic Surveys Report (AESR) 63:1. Ottawa: Department of Northern Affairs and National Resources.

BALIKCI, A. 1964. Development of basic socio-economic units in two Eskimo communities. Bulletin 202. Ottawa: National Museum of Canada. 1970. The Netsilik Eskimo. Garden City, New York: The Natural History Press.

— 1984. Netsilik. In: Damas, D., ed. Handbook of North American Indians, 5: Arctic. Washington, D.C.: The Smithsonian Institution. 415-430.

BELL, R., and HELLER, C. 1978. Nutrition studies: An appraisal of the modern North Alaskan Eskimo diet. In: Jamison, P., Zegura, S., and Milan, F., eds. Eskimos of Northwestern Alaska: A biological perspective. US/IBP Synthesis Series No. 8. Stroudsburg, Pennsylvania: Dowden, Hutchinson \& Ross. $145-156$.

BOAS, F. 1888. The Central Eskimo. Sixth Annual Report of the Bureau of American Ethnology for the Years 1884-1885. Washington, D.C.: The Smithsonian Institution. 399-699.

BORRÉ, K. 1990. A bio-cultural model of dietary decision making among North Baffin Island Inuit: Explaining the ecology of food consumption by Native Canadians. Unpublished Ph.D dissertation, Department of Anthropology, University of North Carolina, Chapel Hill.

1994. The healing power of the seal: The meaning of Inuit health practice and belief. Arctic Anthropology 31(1):1-15.

BUIJS, C. 1993. The disappearance of traditional meat-sharing systems among some Inuit groups of Canada and Greenland. In: Buijs, C., ed. Continuity and discontinuity in Arctic cultures. Leiden: National Museum of Ethnology. 108-135.

BURCH, E.S., Jr. 1985. Subsistence production in Kivalina, Alaska: A twenty year retrospective. Division of Subsistence Technical Paper Series No. 128. Juneau: Alaska Department of Fish and Game.

CLANCY, P. 1987. The making of Eskimo policy in Canada, 1952-62: The life and times of the Eskimo Affairs Committee. Arctic 40(3): 191-197.

COLLINGS, P. 1997. Subsistence hunting and wildlife management in the Central Canadian Arctic. Arctic Anthropology 34(1): 41-56.

CONDON, R.G. 1987. Inuit youth: Growth and change in the Canadian Arctic. New Brunswick, New Jersey: Rutgers University Press.

1992. Changing patterns of conflict management and aggression among Inuit youth in the Canadian Arctic: Longitudinal Ethnographic Observations. Native Studies Review 8:35-49.

- 1996. The northern Copper Eskimo: A history. Norman, Oklahoma: University of Oklahoma Press.

CONDON, R.G., COLLINGS, P., and WENZEL, G.W. 1995. The best part of life: Subsistence hunting, ethnicity, and economic adaptation among young adult Inuit males. Arctic 48(1):31-46. 
DAMAS, D. 1969a. Introduction: The study of cultural ecology and the ecology conference. In: Damas, D., ed. Contributions to anthropology: Ecological essays. Anthropological Series 84, Bulletin 230. Ottawa: National Museum of Canada. 1-12.

. 1969b. Characteristics of Central Eskimo band structure. In: Damas, D., ed. Contributions to anthropology: Band societies. Anthropological Series 84, Bulletin 228. Ottawa: National Museum of Canada. 116-134.

. 1969c. Environment, history, and Central Eskimo society. In: Damas, D., ed. Contributions to anthropology: Ecological essays. Anthropological Series 86, Bulletin 230. Ottawa: National Museum of Canada. 40-64.

. 1972a. The Copper Eskimo. In: Bicchieri, M., ed. Hunters and gatherers today: A socioeconomic study of eleven such cultures in the twentieth century. New York: Holt, Rinehart and Winston. 3-50.

1972b. Central Eskimo systems of food sharing. Ethnology 11(3):220-240.

— 1975. Three kinship systems from the Central Arctic. Arctic Anthropology 12(1):10-30.

-1976. The problem of the Eskimo family. In: Ishwaran, K., ed. The Canadian family. Toronto: Holt, Rinehart and Winston. $54-78$.

- 1984. Copper Eskimo. In: Damas, D., ed. Handbook of North American Indians, 5: Arctic. Washington, D.C.: The Smithsonian Institution. 397-414.

. 1993. Shifting relations in the administration of Inuit: The Hudson's Bay Company and the Canadian Government. Études/ Inuit/Studies 17(2):5-28.

DRAPER, H. 1976. A review of recent nutritional research in the Arctic. In: Shephard, R., and Itoh, S., eds. Circumpolar Health: Proceedings of the 3rd International Sumposium, Yellowknife, Northwest Territories. Toronto: University of Toronto Press. $120-164$.

_- 1978. Nutrition studies: The Aboriginal Eskimo diet - A modern perspective. In: Jamison, P., Zegura, S., and Milan, F., eds. Eskimos of northwestern Alaska: A biological perspective. US/IBP Synthesis Series 8. Stroudsburg, Pennsylvania: Dowden, Hutchinson \& Ross. 139-144.

- 1980. Nutrition. In: Milan, F., ed. The human biology of circumpolar populations. Cambridge and London: Cambridge University Press. 257-284.

FABIJAN, M. 1991. Inuvialuit Harvest Study data report (January 1990-December 1990). Inuvik, Northwest Territories: Inuvialuit Game Council.

FALL, J. 1990. The Division of Subsistence of the Alaska Department of Fish and Game: An overview of its research program and findings, 1980-1990. Arctic Anthropology 27(2):68-92.

GARDNER, P. 1991. Foragers' pursuit of individual autonomy. Current Anthropology 32(5):543-572.

HENSEL, C. 1992. Where it's still possible: Subsistence, ethnicity and identity in south west Alaska. Unpublished Ph.D. Thesis, University of California, Berkeley, California.

HUNTINGTON, H. 1992. Wildlife management and subsistence hunting in Alaska. London: Belhaven Press.
JELLISS, A. 1978. Report on the impact of depressed sealskin prices in the Northwest Territories. Unpubl. Report, Economic Analysis Division. Ottawa: Department of Indian Affairs and Northern Development. 14 p.

JENNESS, D. 1922. The life of the Copper Eskimos. Report of the Canadian Arctic Expedition, 1913-1918. Vol. 12(A). Ottawa.

KISHIGAMI, N. 1995. Extended family and food sharing practices among the contemporary Netsilik Inuit: A case study of Pelly Bay, NWT, Canada. Journal of Hokkaido University of Education 45(2):1-9.

LANGDON, S. 1981. Anthropological economics, Part 1. In: Langdon, S., and Worl, R., eds. Distribution and exchange of subsistence resources in Alaska. Division of Subsistence, Technical Paper No. 55. Anchorage, Alaska: Alaska Department of Fish and Game. 54 p.

LOWE, R. 1983. Kangiryuarmiut Uqauhingita Numiktittitdjutingit/ Basic Kangiryuarmiut Eskimo Dictionary. Inuvik, N.W.T.: Committee for Original Peoples' Entitlement.

NUTTALL, M. 1992. Arctic homeland: Kinship, community and development in Northwest Greenland. Toronto: University of Toronto Press.

PARRY, W. 1824. Journal of a second voyage for the discovery of a Northwest Passage from the Atlantic to the Pacific: Performed in the years 1821-22-23, in His Majesty's Ships Fury and Hecla. London: John Murray.

PRICE, J. 1975. Sharing: The integration of intimate economies. Anthropologica (N.S.) 17 (1):3-27.

RASMUSSEN, K. 1929. Intellectual culture of the Iglulik Eskimo. Report of the Fifth Thule Expedition 1921-24. Vol. 6, No.1. Copenhagen: Glydendalske Boghandel.

. 1932. Intellectual life of the Copper Eskimo. Report of the Fifth Thule Expedition 1921-24. Vol. 9. Copenhagen: Glydendalske Boghandel.

REMIE, C. 1984. How Ukpaktoor lost his buttock and what he got in exchange for it: Cultural changes amongst the Arviligdjuarmiut of Pelly Bay, Northwest Territories, Canada. In: Nooter, G., ed. Life and survival in the Arctic: Cultural changes in the Polar regions. The Hague: Government Printing Office. 97-120.

SAHLINS, M. 1965. On the sociology of primitive exchange. In: Banton, M., ed. The relevance of models for social anthropology. Association of Social Anthropology Monographs I. London. $139-236$.

- 1972. Stone Age economics. Chicago: Aldine.

SCHAEFER, O. 1971. When the Eskimo comes to town. Nutrition Today 5 (November/December):8-16.

SMITH, E.A. 1991. Inujjuamiut foraging strategies: Evolutionary ecology of an Arctic hunting economy. New York: Aldine de Gruyter.

SMITH, T.G., and WRIGHT, H. 1989. Economic status and role of hunters in a modern Inuit village. Polar Record 25:93-98.

SPENCER, R. 1959. The North Alaska Eskimo: A study in ecology and society. Bureau of American Ethnology Bulletin 171. Washington, D.C.

STEFANSSON, V. 1913. My life with the Eskimo. New York : MacMillan.

1921. The friendly Arctic: The story of five years in Polar regions. New York:MacMillan. 
STEWARD, J. 1955. Theory of culture change: The methodology of multilinear evolution. Urbana, Illinois: University of Illinois Press.

STEVENSON, M. 1997. Inuit, whalers, and cultural persistence: Structure in Cumberland Sound and Central Inuit social organization. Don Mills, Ontario: Oxford University Press Canada.

USHER, P.J. 1965. Economic basis and resource use of the Coppermine-Holman Region, NWT. (NCRC-65-2) Ottawa: Department of Northern Affairs and National Resources.

VAN DE VELDE, F. 1956. Rules for sharing the seals amongst the Arviligjuarmiut. Eskimo 41:3-6.

WEIN, E., and FREEMAN, M.M.R. 1992. Inuvialuit food use and food preferences in Aklavik, Northwest Territories, Canada. Arctic Medical Research 51:159-172.

WENZEL, G.W. 1981. Clyde Inuit ecology and adaptation: The organization of subsistence. Canadian Ethnology Service Mercury Paper No. 77. Ottawa: National Museums of Canada. . 1987. "I was once independent": The southern seal protest and Inuit. Anthropologica 29:195-210.
1989. Sealing at Clyde River, N.W.T.: A question of economy. Études/Inuit/Studies 13(1):3-22.

. 1991. Animal rights, human rights: Ecology, economy and ideology in the Canadian Arctic. Toronto: University of Toronto Press.

1994. Recent change in Inuit summer residence patterning on East Baffin Island. In: Burch, E.S., Jr., and Ellanna, L., eds. Key issues in hunter-gatherer research. Oxford: Berg. 289-308.

___ 1995. Ningiqtuq: Resource sharing and generalized reciprocity in Clyde River, Nunavut. Arctic Anthropology 32(2):43-60.

WOLFE, R.J., and WALKER, R. 1987. Subsistence economies in Alaska: Productivity, geography, and development impacts. Arctic Anthropology 24(2):56-81.

WORL, R. 1980. The North Slope Inupiat whaling complex. In: Kotani, Y., and Workman, W., eds. Alaska Native culture and history. Senri Ethnological Studies 4. Osaka: National Museum of Ethnology. 305-322. 